\title{
Protein supplementation for severely undernourished ewes
}

\author{
P Kabré, M Petit, H Tournadre \\ INRA, laboratoire Lactation et Élevage des ruminants, Theix, 63122 Saint-Genès-Champanelle, France
}

Eight non-pregnant non-lactating Limousin $x$ Romanov mature ewes initially weighing $56 \mathrm{~kg}$ were used to investigate the effects of protein supplementation on the digestibility of a medium-quality forage and on body weight loss when energy supply was severely restricted.

During the first $26 \mathrm{~d}$ of the trial, all ewes were fed on a meadow hay (organic matter (OM): 937 g; crude protein (CP): $107 \mathrm{~g}$; crude fiber (CF): $328 \mathrm{~g}$ per $\mathrm{kg}$ dry matter) to cover $50 \%$ of their daily energy and protein maintenance requirements (INRA, 1989), ie $\approx 200 \mathrm{~kJ}$ metabolizable energy (ME) and $1.36 \mathrm{~g} \mathrm{PDI} / \mathrm{kg} \mathrm{LW} 0.75 / \mathrm{d}$. They were then allotted to 2 groups of 4 animals each. Control ewes continued to receive the initial diet for another $74 \mathrm{~d}$, while the others were supplemented with $60 \mathrm{~g} / \mathrm{d}$ fish meal (FM group) in order to receive $200 \mathrm{~kJ} \mathrm{ME}$ and $2.72 \mathrm{PDI} / \mathrm{kg}$ intial LW $0.75 / \mathrm{d}$. Diet digestibility was measured in all ewes during the last 3 wk of the trial.

The FM ewes lost less body weight than the controls (96 vs $134 \mathrm{~g} / \mathrm{d} ; P<0.03$ ) probably because of their higher ME intake
(218 vs $199 \mathrm{~kJ} / \mathrm{kg}$ initial LW0.75/d for FM and control ewes respectively; $P<0.03$ ). This was principally due to the higher digestibility of the hay in the FM $++7-9 \%$ for crude fiber and energy). Such an improvement in digestibility has often been observed but only with forages of lower $\mathrm{N}$ content (like straw) than the hay in the present study (eg Ortigues et al, 1989). In the control diet, the estimated degraded $\mathrm{N}$ in the rumen (INRA, 1989) was $21 \mathrm{~g} \mathrm{~N} / \mathrm{kg}$ digestible $\mathrm{OM}$, and approximately covered the ammonia need of the micro-organisms (INRA, 1989) suggesting that fish meal provided additional specific nutrients (such as amino acids) which promoted microbial activity and fiber digestion.

Ortigues I, Smith T, Oldham JD, McAllan AB, Siviter JW (1989) Br J Nutr 62, 601-619

INRA (1989) Ruminant Nutrition (Jarrige R, ed) INRA, Paris

Table I. Average intake and digestibility of chemical components of the diets.

\begin{tabular}{|c|c|c|c|c|c|c|c|c|}
\hline \multirow{2}{*}{ Group } & \multicolumn{4}{|c|}{ Intake $(g / d)$} & \multicolumn{4}{|c|}{ Digestibility (\%) } \\
\hline & $O M$ & $C P$ & $C F$ & $G E^{1}$ & $O M$ & $C P$ & $C F$ & Energy \\
\hline Control & 464 & 53 & 160 & 9.29 & 57 & 52 & 57 & 54 \\
\hline SE & 25 & 3 & 9 & 0.50 & 2 & 2 & 2 & 2 \\
\hline FM & 438 & 84 & 133 & 9.02 & $64^{\star \star}$ & $72^{* \star}$ & $61^{*}$ & $62^{* *}$ \\
\hline$S E$ & 24 & 6 & 7 & 0.50 & 2 & 1 & 2 & 2 \\
\hline
\end{tabular}

${ }^{1}$ GE gross energy $(\mathrm{MJ} / \mathrm{d}) ;{ }^{* *} P<0.03 ;{ }^{*} P<0.06$ 